\title{
Characterization of a critically ill population with legionella pneumonia during a severe community outbreak in portugal
}

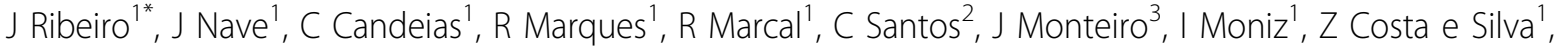 \\ C Franca $^{1}$
}

From ESICM LIVES 2015

Berlin, Germany. 3-7 October 2015

\section{Introduction}

A major community outbreak of Legionnaire' disease occurred in the great region of Lisbon, from October to December 2014. This outbreak resulted in a large number of patients developing severe pneumonia and demanding treatment in intensive care units (ICU). Information regarding this specific population of patients with severe Legionella pneumonia is very scarce in the literature.

\section{Objectives}

Clinical, functional, laboratorial, and prognostic characterization of the population of patients with the most severe forms of Legionella pneumonia treated in an ICU.

\section{Methods}

Prospective registration and statistical analysis of data based on a protocol specifically designed for the population of 24 patients with Legionella pneumonia admitted to ICU.

\section{Results}

From October to December a community outbreak of Legionnaire's disease infected 375 patients. Sequencebased typing of clinical and environmental isolates confirmed industrial wet cooling systems as the source of infection. Seventy-six patients were treated at our hospital, of which twenty-four demanded ICU admission, mainly due to severe hypoxemic respiratory failure. Median age were $56.9 \pm 11.9$ (20-77), with a preponderance of male sex (17 vs. 7). SAPS II score was $41.25 \pm 16.61$, SOFA at admission was $6.7 \pm 3.1$ and mean number of failing

'University Hospital of Santa Maria, Intensive Care Department, Lisbon,

Portugal

Full list of author information is available at the end of the article organs was $2.8 \pm 1.4$. Sixteen patients $(66.7 \%)$ demanded invasive mechanical ventilation, and 6 patients had to be rescued by extracorporeal membrane oxygenation (median time of ECMO run of $7.5 \pm 2.3$ ). ICU and hospital length of stay were $14.3 \pm 4.7$ and $25.6 \pm 14.0$, respectively, and hospital mortality was $8,3 \%$ ( 2 patients). Patients were treated with azithromycin (17) or levofloxacin (7 patients). A moderate correlation was identified between the mean time to a $50 \%$ value reduction of $\mathrm{C}$-reactive protein and hospital LOS; degree of hypoxemia at admission (Pa02: Fi02 147.2 \pm 86.8 ) moderately predicted the need for ECMO; SAPS II and C-reactive protein value at admission $(45.8 \pm 39.9 \mathrm{mg} / \mathrm{dl})$ did not correlate with LOS (ICU or hospital) nor with the need for ECMO.

\section{Conclusions}

The authors characterize a population of patients with Legionella pneumonia that needed an ICU-based treatment approach. To the best of their knowledge, this is one of the biggest series of patients with a diagnosis of Legionella pneumonia that evolved to the most severe forms of the disease and should contribute to a better understanding of this entity.

\section{Grant Acknowledgment}

No grant disclosures.

\section{Authors' details}

'University Hospital of Santa Maria, Intensive Care Department, Lisbon, Portugal. ${ }^{2}$ University Hospital Santa Maria, Infectious Diseases Department, Lisbon, Portugal. ${ }^{3}$ University Hospital Santa Maria, Pulmonology Department, Lisbon, Portugal.
(C) 2015 Ribeiro et al.; This is an Open Access article distributed under the terms of the Creative Commons Attribution License (http:// creativecommons.org/licenses/by/4.0), which permits unrestricted use, distribution, and reproduction in any medium, provided the original work is properly cited. 


\section{References}

1. A large community outbreak of Legionnaires' disease in Vila Franca de Xira, Portugal, October to November 2014. Euro Surveill 2014, 19(50): pii-20991.

2. Phin N, Parry-Ford F, Harrison T, et al: Epidemiology and clinical management of Legionnaires' disease. Lancet Infect Dis 2014, 14:1011-21.

doi:10.1186/2197-425X-3-S1-A354

Cite this article as: Ribeiro et al:: Characterization of a critically ill population with legionella pneumonia during a severe community outbreak in portugal. Intensive Care Medicine Experimental 2015

3(Suppl 1):A354.

\section{Submit your manuscript to a SpringerOpen ${ }^{\mathcal{O}}$ journal and benefit from:}

- Convenient online submission

- Rigorous peer review

- Immediate publication on acceptance

- Open access: articles freely available online

- High visibility within the field

- Retaining the copyright to your article

Submit your next manuscript at $\gg$ springeropen.com 